\title{
AZ EMBERI TEST KÜLTÉRI HŐTERHELÉSÉNEK A HUMÁN ÁLLAPOTHATÁROZÓKTÓL VALÓ FÜGGÉSE
}

\author{
Zsákai Annamária ${ }^{1}$, Fehér Piroska ${ }^{1}$, Annár Dorina ${ }^{l}$, Kristóf Erzsébet $^{2,3}$ és Ács Ferenc ${ }^{2}$
}

\author{
${ }^{1}$ Embertani Tanszék, Eötvös Loránd Tudományegyetem, Budapest; \\ ${ }^{2}$ Meteorológia Tanszék, Eötvös Loránd Tudományegyetem, Budapest; \\ ${ }^{3}$ Kiválósági Tudásközpont, Eötvös Loránd Tudományegyetem, Budapest
}

Zsákai A., Fehér P., Annár D., Kristóf E., Ács F.: The dependence of outdoor human body thermal load on human state variables. A new clothing resistance model for estimating outdoor thermal load of a walking individual has been proposed by our research team. The model is used as a tool to analyse the relationship between clothing resistance (estimated by this new model) and body structural parameters in different weather conditions. More than 3000 children's and adults' body structural - BMI, relative fat mass (fatBMI) and relative muscle mass (muscleBMI) data, as well as simulated data of weather conditions having influence on thermal perception were used in the analysis. The relationship between BMI, fatBMI, muscleBMI and clothing resistance showed very strong relations both in simulated winter and summer conditions, in both sexes in almost every agegroup. The bigger the BMI, fatBMI, muscleBMI, the smaller clothing resistance (smaller heating demand) was estimated in winter weather conditions, while the bigger clothing resistance (smaller cooling demand) was estimated in summer weather conditions. Females' clothing resistance was higher in winter weather conditions, while was smaller in summer conditions than the clothing resistance of their male age-peers having the same relative body mass, fat mass or muscle mass. BMI showed the strongest relations with clothing resistance both in summer and winter thermal stresses. The preliminary results of the project confirmed that age, gender, BMI and presumably relative fat and muscle mass should be built in the procedure of parameterization of clothing resistance.

Keywords: Weather conditions; Thermal load; Clothing resistance; Body structural parameters; Body mass index.

\section{Bevezetés}

Környezetünk tényezöinek komfortosnak érzett tartományoktól való jelentős eltérése szervezetünk számára stresszként jelenik meg. Az érzékelő rendszerünknek az egyik ilyen fontosabb, a komfortérzetünket felügyelö, több időjárási tényező által meghatározott eleme a hőérzékelő rendszerünk. Az ember környezeti hőterhelését az emberi test sugárzási egyenlege, a léghőmérséklet, a légnedvesség és a szélsebesség határozza meg. Hőérzetünket a környezeti hőterhelésen kívül számos további környezeti és humán tényező befolyásolja. Hőérzetünk szubjektív, hiszen azonos mértékü környezeti hőterheléssel kiváltott hőérzet jelentős egyedi különbségeket mutathat, így például különböző életkorú, nemü, testalkatú, ill. fizikai aktivitású emberek höérzete jelentös mértékben különbözhet. Mindezen tényezőkön túl höérzetünket, a termikus környezeti viszonyokra vonatkozó szubjektív értékelésünket jelentősen befolyásolhatja még például termikus elóéletünk, testhelyzetünk, egészségi állapotunk és természetesen ruházatunk is (Ács és mtsai 2020a, b).

A termikus komfortérzetünk akkor valósulhat meg, ha a testünk energia-beviteli és -leadási folyamatai a lehető legkisebb energia-ráfordítással egyensúlyban tarthatók 
(Kántor 2012). A ruházat mértékének változtatásával képesek vagyunk a hüvös, illetve hideg időjárási viszonyokat is elviselni, ezen viszonyok között akár még komfortosnak is érezni állapotunkat. Azonban a ruhaipar nem tud ruházati megoldást nyújtani egyelöre a meleg időjárási viszonyok során kialakuló hőérzet komfortos zóna felé történő elmozdításában, ugyanis nincs még olyan típusú ruhadarab forgalomban, amely jelentős mértékben hüsítené az emberi testet, az extrém meleg időjárási viszonyokat elviselhetőbbé tenné számunkra.

A kültéri környezeti humán hőterhelés kérdésköre közel egy évszázados múltra tekint vissza (de Freitas and Grigorieva 2015). Eleinte csak a környezeti tényezők vizsgálatával foglalkoztak (Haldane 1905) teljesen mellőzve a humán tényezők szerepét. A múlt század derekán jelentek meg az első olyan modellek, amelyek az emberi test energiaegyenlegén alapultak, és így a humán tényezők számításba vétele is lehetségessé vált (Budyko és Cicenko 1960). E modellek közül az ún. PMV (Predicted Mean Vote), PET (Physiologically Equivalent Temperature) és UTCI (Universal Thermal Climate Index) index-modellek a legelterjedtebbek. Hangsúlyozzuk ki, hogy ezek energiaegyenleg-alapú modellek, ezért igen komplexek, függetlenül attól, hogy index-modelleknek nevezzük őket. Magyarországon és Kárpát-medence térségében az ún. ruházati index-modell is használatos (Ács és mtsai 2019, 2020a, b), amely szintén az emberi test energiaegyenlegének számításán alapul, de az emlegetett index-modelleknél sokkal egyszerübb. Megemlítendő az is, hogy a humán állapothatározókat (nem, kor, testtömeg, testmagasság) ugyanúgy számításba veszi, mint az ismert PET vagy UTCI indexmodellek. A modellünk lehetővé teszi azt is, hogy a felsorolt humán állapothatározók mellett más humán jellemzők hőterhelésre gyakorolt hatását is vizsgálhassuk.

Mindezek alapján kutatásunkkal célunk a nem, az életkor, a testalkat és a fizikai aktivitás tervezett mértékének figyelembevételén alapuló, az aktuális időjárási viszonyokhoz ajánlott optimális ruházat egyénre szabott előrejelzésére alkalmas modell kidolgozása. Ehhez elsőként egy normál tempóban gyalogoló ember szervezetét érő kültéri hőterhelés mértékének becslésére alkalmas modellt dolgoztunk ki a környezeti és humán tényezők egyszerü parametrizálásával (Ács és mtsai 2019, 2020a, b). A jelen tanulmány célja a ruházati indexnek, mint energiaegyenleg alapú hőterhelés-mutatónak, a relatív izomtömegtől és a relatív zsírtömegtől való függésének elemzése egy hőtöbblettel, valamint hőhiánnyal járó időjárási helyzetben, hogy beazonosíthassuk a hőterhelést leginkább befolyásoló humán tényezőket.

\section{Vizsgált személyek és alkalmazott módszerek}

Az ELTE TTK Meteorológia Tanszéke és Embertani Tanszéke által indított közös kutatás során kidolgozott modellel (Ács és mtsai 2019, 2020a, b) becsülhető a ruházati index és az ún. operatív hőmérséklet (egy környezeti hőterhelési mutató, amely számításba veszi a sugárzási egyenleget, a hőmérsékletet és a szél hatását a termikus terhelés mértékének becslésekor) a kültéri környezetben gyalogoló (átlagosan 4 km/óra sebességgel) és nem izzadó ember esetében lokális időjárási és/vagy éghajlati viszonyokban. A modell alapján becsülhető ismert időjárás vagy éghajlat, továbbá ismert nem, életkor és testalkat esetében a komfortérzetet nyújtó kültéri ruházat mértéke.

A modell megszerkesztéséhez több, mint 3000 gyermek és felnőtt (1. táblázat) testszerkezeti mutatóit (Utczás és mtsai 2015, Zsákai és Bodzsár 2016, Fehér és mtsai 2019), illetve az Országos Meteorológiai Szolgálat online felületén (www.met.hu) rendelkezésre álló, hőérzékelést befolyásoló időjárási adatait használtuk fel. 
1. táblázat. Vizsgált személyek életkori megoszlása.

Table 1. The distribution of subjects by age.

\begin{tabular}{cc}
\hline Életkor (év) - Age (years) & $\mathrm{n}$ \\
\hline 7 & 167 \\
8 & 191 \\
9 & 185 \\
10 & 231 \\
11 & 191 \\
12 & 171 \\
13 & 193 \\
14 & 173 \\
15 & 172 \\
16 & 183 \\
17 & 135 \\
18 & 108 \\
19 & 103 \\
$20-29$ & 379 \\
$30-39$ & 280 \\
$40-49$ & 117 \\
$50-59$ & 131 \\
$60+$ & 63 \\
Összesen - Together & 3173 \\
\hline
\end{tabular}

A vizsgálatban részvevő gyermekek és felnőttek testméreteit a nemzetköz ajánlások alapján, standard módszerekkel és standard eszközökkel mértük le (Weiner és Lourie 1969). A testösszetevő komponensek mennyiségét az ELTE Embertani Tanszéke tulajdonában lévő InBody 720-as típusú, bőrellenállás mérésen alapuló testösszetételanalizátorral határoztuk meg. A bőrellenállás mérésen alapuló testösszetétel-vizsgálattal becsült, abszolút vázizom- és zsírtömegből a relatív mennyiségüket a testtömeg-indexben használt tömeg és testmagasság aránynak megfelelően számítottuk, az ún. zsírBMI (abszolút zsírtömeg $[\mathrm{kg}] /$ testmagasság ${ }^{2}\left[\mathrm{~m}^{2}\right]$ ) és izomBMI (abszolút izomtömeg $[\mathrm{kg}]$ / testmagasság ${ }^{2}\left[\mathrm{~m}^{2}\right]$ ) mutatókat vezettük be elemzésünk során.

A ruházati index-modell alapegyenleteinek ismertetése mellett bemutatjuk a nagy hőtöbbletet és hőhiányt okozó időjárási helyzet meteorológiai elemeit és részletesen ismertetjük a humán állapothatározók és a termikus komfortérzet eléréséhez becsült ruházat hütő-, illetve fütőhatásának jellemzésére használt ún. ruházati index közötti kapcsolat életkori és nemi mintázatát.

Ruházati index-modell

A ruházati index-modell két alapegyenlete a következő:

$$
\begin{gathered}
r_{c l}=\rho \cdot c_{p} \cdot \frac{T_{S}-T_{O}}{M-\lambda E_{s d}-\lambda E_{r}-W}-r_{H r}, \\
T_{O}=T_{a}+\frac{R_{n i}}{\rho \cdot c_{p}} \cdot r_{H r},
\end{gathered}
$$

ahol $\mathrm{r}_{\mathrm{cl}}$ a ruházati index $[\mathrm{s} / \mathrm{m}], \mathrm{T}_{\mathrm{o}}$ az operatív hömérséklet $\left[{ }^{\circ} \mathrm{C}\right], \rho$ a levegö sürüsége $\left[\mathrm{kg} / \mathrm{m}^{3}\right], \mathrm{c}_{\mathrm{p}}$ a levegö állandó nyomáson vet fajhöje $\left[\mathrm{J} / \mathrm{kg} /{ }^{\circ} \mathrm{C}\right], \mathrm{T}_{\mathrm{S}}$ a bőrfelszín átlagos 
hőmérséklete $\left(34^{\circ} \mathrm{C}\right), \mathrm{T}_{\mathrm{a}}$ a levegő hőmérséklete 2 m-es magasságban $\left[{ }^{\circ} \mathrm{C}\right], \mathrm{R}_{\mathrm{ni}}$ a ruházattal borított emberi test sugárzási egyenlege $\left[\mathrm{W} / \mathrm{m}^{2}\right], \mathrm{r}_{\mathrm{Hr}}$ a sugárzás konvektív hőátvitellel szemben kifejtett ellenállási együttható $[\mathrm{s} / \mathrm{m}], \mathrm{M}$ a $4 \mathrm{~km} / \mathrm{h}$ sebességgel gyalogoló ember metabolikus hőáram-sürüsége $\left[\mathrm{W} / \mathrm{m}^{2}\right], \lambda \mathrm{E}_{\mathrm{sd}}$ a száraz bőr látens hőáram-sürüsége $\left[\mathrm{W} / \mathrm{m}^{2}\right]$, $\lambda \mathrm{E}_{\mathrm{r}}$ a respirációs látens hőáramsürüség és $\mathrm{W}$ a tevékenység során használt izmok mechanikai munkájának áramsürüsége $\left[\mathrm{W} / \mathrm{m}^{2}\right]$. Az $\mathrm{r}_{\mathrm{cl}}$-t általában [clo]-ban fejezik ki, 1 [clo] $=186,7[\mathrm{~s} / \mathrm{m}] . A z \mathrm{r}_{\mathrm{cl}}$ lehet pozitív, nulla körüli és negatív. A pozitív $\mathrm{r}_{\mathrm{cl}}$-értékek höhiányt, a negatív $\mathrm{r}_{\mathrm{cl}}$-értékek hötöbbletet, míg a nulla közeli $\mathrm{r}_{\mathrm{cl}}$-értékek termikus egyensúlyt (sem hőtöbblet, sem hőhiány) fejeznek ki. Az $\mathrm{r}_{\mathrm{cl}}$ a $\mathrm{T}_{\mathrm{o}}$-on keresztül erősen függ a környezeti hőterheléstől, míg az M-en keresztuil a humán állapothatározóktól is. Megemlítendő az is, hogy egyes humán állapothatározók, pl. a testtömeg, függhetnek olyan jellemzőktől is mint az emberi test százalékban kifejezett zsírtartalma vagy izomtömege. Ez az áttételes függés az M-en keresztuil az $\mathrm{r}_{\mathrm{cl}}$ értékére is módosítólag hathat.

\section{A nagy hötöbbletet és hőhiányt okozó időjárási helyzet meteorológiai elemeinek bemutatása}

A vizsgálatok elvégzéséhez egy viszonylag hideg téli és egy meleg nyári csapadékmentes, gyengén szeles időjárási helyzetet választottunk (Martonvásárt választva a modellezés helyszínéül). A hőhiányt okozó időjárási helyzetet teljesen borult ég, elhanyagolható mértékü UV-sugárzás, $-10^{\circ} \mathrm{C}$-os hőmérséklet, $2,2 \mathrm{~m} / \mathrm{s}$ átlagos szélsebesség, 85\%-os relatív nedvesség és 1117 hPa légnyomás jellemezte. A hötöbbletet okozó időjárási helyzetben $33^{\circ} \mathrm{C}$-os léghőmérsékletet, $1118 \mathrm{hPa}$ légnyomást, $1,7 \mathrm{~m} / \mathrm{s}$ átlagos szélsebességet és $40 \%$-os relatív nedvességet mértek, miközben az égbolt felhőzetmentes volt (erős UV-sugárzás). Szinte ugyanakkora légnyomás értékek esetén egészen különböző időjárási viszonyok uralkodtak (1. ábra), ezzel egészen különböző hőterhelést gyakorolva az emberi szervezetre.

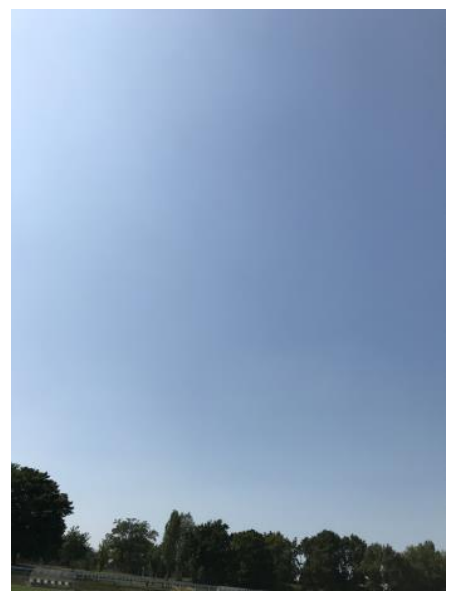

A

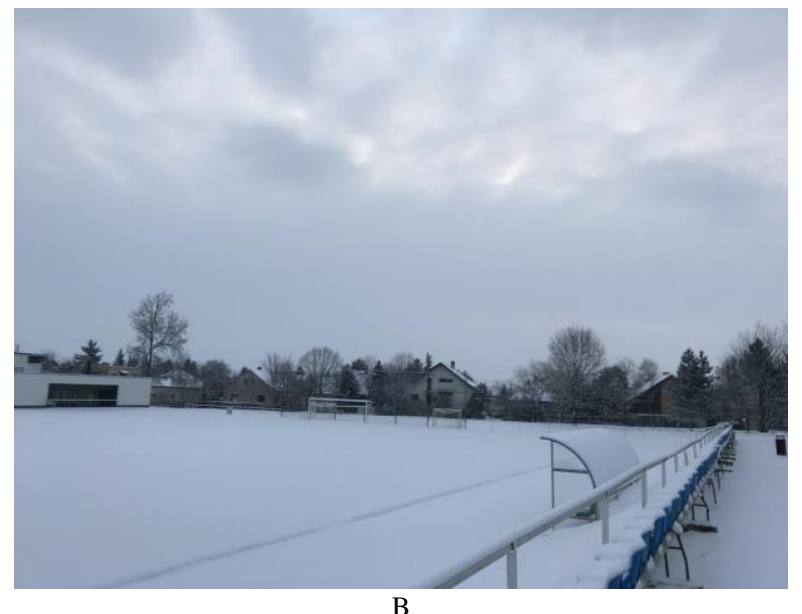

1. ábra: Martonvásár égboltképe két merőben különböző és extrém időjárási helyzetben

(A) 2017. augusztus 26-án (nagy hötöbblet) és (B) 2018. február 28-án (nagy höhiány).

Fig. 1: Sky view of Martonvásár in two very different weather conditions (A) on the 26th of August, 2017 (in large surplus of heat) and (B) on the 28th of February, 2018 (in large deficit of heat). 


\section{Statisztikai elemzések}

A vizsgált testszerkezeti mutatók nem normális eloszlásúak (Kolmogorov-Szmirnov teszt, p<0,001 a BMI, a zsírBMI és az izomBMI esetében is), ezért két vizsgált változó közötti kapcsolat jellemzésére a Spearman-féle korrelációs elemzést (rho: korrelációs koefficiens), az alcsoportok összehasonlításakor pedig a Mann-Whitney és a KruskalWallis - teszteket alkalmaztuk. Az alcsoportokba sorolt vizsgált személyek egyedi ruházati indexeinek testszerkezeti mutatóik szerinti eloszlásmintázatainak összehasonlításakor a mutatók eloszlásmintázatai alapján szerkesztett centilismintázatokat (3., 10., 25., 50., 75., 90., 97. centiliseket becsültük) vettük figyelembe. A centilis-mintázatokat az lmsChartMaker Pro 2.3 (Medical Research Council, UK 19972006) szoftverrel szerkesztettük meg. Az alcsoportok páros összehasonlításakor az alcsoportok saját és másik alcsoport centilis-mintázata mellett teszteltük a centilisövekben elhelyezkedő egyedi értékek eloszlása hasonlóságának mértékét $\chi^{2}$-próbával. Kettőnél több alcsoport esetében az alcsoportok többszörös páros összehasonlításait végeztük el.

Hipotéziseinket 5\%-os szignifikancia-szinten teszteltük. A statisztikai elemzések során és az ábrák szerkesztésekor az SPSS v. 23.0 és az R programcsomagokat (R Core Team 2020) használtuk. A ruházati index és a testösszetevők kapcsolatának bemutatásához készített ábráinkon az áttekinthetőség érdekében a vizsgált korcsoportok 125-125 vizsgálati alanyát választottuk ki az R programcsomag „sample” függvényét alkalmazva, véletlenszerúen mindkét nem esetében. Az alcsoportok összehasonlításakor a teljes létszámú alcsoportok kerültek be a statisztikai elemzésekbe.

\section{Vizsgálati eredmények és megvitatásuk}

A testszerkezeti mutatók és a ruházati index kapcsolatának elemzése

A testszerkezeti mutatók és a ruházati index kapcsolatának vizsgálatába bevont mutatók jelentős életkori és nemi különbségeit igazoltuk a gyermekek és felnőttek vizsgált mintájában (2. táblázat). A relatív zsír- és izomtömeg jellemzésére bevezetett zsírBMI és izomBMI is jelentősen különbözött a két nem szinte minden korcsoportjában, a leány/nők relatív zsírtömege, míg a fiúk/férfiak relatív izomtömege meghaladta ellentétes nemü kortársaikét. A 12 évesek korcsoportjától mindkét mutató esetében jelentősen megnőtt az azonos korú fiúk és leányok, illetve férfiak és nők korcsoportos mediánjában ez a különbség, az izomBMI esetében a vizsgált korintervallum végén ez a nemi különbség megszünt. A testtömeg-index nemi különbségének felnőttkorig igazolható hiánya a relatív zsír- és izomtömeg elöbbiekben bemutatott, ellentétes nemi különbségeinek kiegyenlítő hatásának tudható be. A ruházati index esetében a modell a termikus komfortérzet eléréséhez a leányok/nők esetében télen nagyobb fütő-, nyáron nagyobb hütőértékű kültéri ruházatot becsült fiú/férfi kortársaikhoz viszonyítva végig a vizsgált korintervallumon (2. táblázat).

A zsírosság mértékének becslésére bevezetett zsírBMI növekedésével mindkét nem, minden korcsoportjában a termikus komfortérzet elérésére becsült ruházati index csökkenése figyelhető meg (2. ábra). A zsírBMI ötszörös különbsége $\left(2 \mathrm{~kg} / \mathrm{m}^{2} \rightarrow 10\right.$ $\mathrm{kg} / \mathrm{m}^{2}$ ) átlagosan 0,5 clo-egységnyi hőszigetelésbeli különbséget jelent, azaz egy $10 \mathrm{~kg} / \mathrm{m}^{2}$ zsírBMI-vel rendelkező felnőtt férfi számára 0,5 clo-nyival vékonyabb ruházat biztosít termikus komfortérzetet egy $2 \mathrm{~kg} / \mathrm{m}^{2}$ zsírBMI-vel jellemezhető férfi kortársához viszonyítva. 0,5 clo nagyjából egy vastagabb pulóver hőszigetelő képességének felel meg, míg a 2, ill. $10 \mathrm{~kg} / \mathrm{m}^{2}$ zsírBMI különbsége $170 \mathrm{~cm}$ magasságú férfiak esetében körülbelül 
30\%-nyi zsírszázalékbeli különbséget jelöl, azaz egy normál tápláltsági állapotú férfi és egy elhízott, azonos testmagasságú férfi zsírBMI értékei különbségének felel meg.

2. táblázat. A vizsgált testszerkezeti mutatók és a ruházati index korcsoportos mediánjai (M: fiúk/férfiak, F: leányok/nők; *: szignifikáns nemi különbség, $\mathrm{p}<0,05$, Mann-Whitney - teszt; korcsoportok mentén minden mutató jelentősen különbözött mindkét nemben, Kruskal-Wallis teszt, $\mathrm{p}<0,001)$.

Table 2. The age-group medians of the studied body structural and clothing indices (M: males, F: females; *: significant sexual dimorphism, $\mathrm{p}<0.05$, Mann-Whitney test; all the studied indices revealed significant age differences in both sexes, Kruskal-Wallis test, $\mathrm{p}<0.001$ ).

\begin{tabular}{|c|c|c|c|c|c|c|c|c|c|c|}
\hline \multirow{3}{*}{$\begin{array}{l}\text { Korcsoport } \\
\text { (év) - Age- } \\
\text { group (ys) }\end{array}$} & \multirow{2}{*}{\multicolumn{2}{|c|}{$\begin{array}{c}\mathrm{BMI} \\
\left(\mathrm{kg} / \mathrm{m}^{2}\right)\end{array}$}} & \multirow{2}{*}{\multicolumn{2}{|c|}{$\begin{array}{c}\text { zsírBMI - } \\
\text { fatBMI } \\
\left(\mathrm{kg} / \mathrm{m}^{2}\right)\end{array}$}} & \multirow{2}{*}{\multicolumn{2}{|c|}{$\begin{array}{l}\text { izomBMI - } \\
\text { muscleBMI } \\
\left(\mathrm{kg} / \mathrm{m}^{2}\right)\end{array}$}} & \multicolumn{4}{|c|}{$\begin{array}{l}\text { Ruházati index - Clothing } \\
\text { resistance }\end{array}$} \\
\hline & & & & & & & \multicolumn{2}{|c|}{ Téli - Winter } & \multicolumn{2}{|c|}{ Nyári-Summer } \\
\hline & M & $\mathrm{F}$ & $M$ & $\mathrm{~F}$ & $\mathrm{M}$ & $\mathrm{F}$ & M & $\mathrm{F}$ & M & $\mathrm{F}$ \\
\hline 7 & 15,73 & 15,80 & $1,98 *$ & 2,33 & $7,06^{*}$ & 6,71 & $2,00 *$ & 2,20 & $-2,36^{*}$ & $-2,50$ \\
\hline 8 & 16,07 & 15,89 & $2,07 *$ & 2,61 & $7,22 *$ & 6,80 & $2,03 *$ & 2,22 & $-2,38 *$ & $-2,52$ \\
\hline 9 & 16,72 & 16,19 & $2,23 *$ & 2,79 & $7,53 *$ & 6,96 & $2,06^{*}$ & 2,26 & $-2,40 *$ & $-2,55$ \\
\hline 10 & 17,26 & 16,83 & $2,50 *$ & 3,02 & $7,57 *$ & 7,26 & $2,08 *$ & 2,26 & $-2,41 *$ & $-2,55$ \\
\hline 11 & 17,17 & 17,62 & $2,46^{*}$ & 3,09 & $7,89 *$ & 7,53 & $2,11^{*}$ & 2,26 & $-2,44^{*}$ & $-2,55$ \\
\hline 12 & 17,53 & 17,95 & $2,15^{*}$ & 3,20 & $8,03 *$ & 7,96 & $2,14 *$ & 2,29 & $-2,46 *$ & $-2,57$ \\
\hline 13 & 19,31 & 19,22 & $2,62 *$ & 3,77 & $8,90^{*}$ & 8,23 & $2,15^{*}$ & 2,27 & $-2,47 *$ & $-2,56$ \\
\hline 14 & $19,45^{*}$ & 20,20 & $2,11 *$ & 4,68 & $9,09 *$ & 8,48 & $2,18 *$ & 2,25 & $-2,49 *$ & $-2,54$ \\
\hline 15 & 20,52 & 20,21 & $2,45^{*}$ & 4,32 & $10,02 *$ & 8,62 & $2,19 *$ & 2,26 & $-2,49 *$ & $-2,55$ \\
\hline 16 & 20,59 & 21,08 & $2,18 *$ & 5,17 & $10,29 *$ & 8,56 & $2,19 *$ & 2,23 & $-2,50 *$ & $-2,53$ \\
\hline 17 & $21,78^{*}$ & 20,58 & $2,47 *$ & 4,99 & $10,98^{*}$ & 8,45 & $2,15^{*}$ & 2,27 & $-2,47 *$ & $-2,56$ \\
\hline 18 & 22,19 & 21,76 & $2,49 *$ & 5,81 & $10,79 *$ & 8,82 & $2,14^{*}$ & 2,20 & $-2,46^{*}$ & $-2,50$ \\
\hline 19 & 22,05 & 20,48 & $2,41 *$ & 4,88 & $10,45^{*}$ & 8,47 & 2,12 & 2,29 & $-2,45$ & $-2,57$ \\
\hline $20-29$ & $23,38^{*}$ & 21,59 & $3,86^{*}$ & 5,68 & $11,05^{*}$ & 8,52 & $2,08 *$ & 2,24 & $-2,42 *$ & $-2,53$ \\
\hline $30-39$ & $26,18^{*}$ & 23,70 & 6,66 & 7,43 & $10,93 *$ & 8,96 & $1,99 *$ & 2,17 & $-2,35^{*}$ & $-2,48$ \\
\hline $40-49$ & $27,07^{*}$ & 24,32 & 7,12 & 7,58 & $11,11^{*}$ & 9,21 & $2,03^{*}$ & 2,16 & $-2,38 *$ & $-2,48$ \\
\hline $50-59$ & $33,50 *$ & 26,80 & 10,67 & 10,07 & $11,57 *$ & 9,20 & $1,81 *$ & 2,10 & $-2,22 *$ & $-2,43$ \\
\hline $60+$ & 31,74 & 28,12 & 10,54 & 10,41 & $12,01 *$ & 9,23 & 1,86 & 2,08 & $-2,26$ & $-2,42$ \\
\hline
\end{tabular}

A zsírBMI és a ruházati index téli időjárási viszonyokra becsült kapcsolatát elemezve a két mutató nagyon szoros, negatív kapcsolata igazolható minden korcsoportban, mindkét nem esetében (Spearman korreláció, p<0,001 - fiúk és férfiak: 7-9 évesek: rho= -0,598, 10-14 évesek: rho=-0,755, 15-18 évesek: rho=-0,773, felnőttek: rho=-0,873; leányok és nők: 7-9 évesek: rho=-0,724, 10-14 évesek: rho=-0,870, 15-18 évesek: rho= $-0,859$, felnőttek: rho=-0,897). Azonban jelentős életkori különbség igazolható a zsírosság ezen mutatója és a ruházati index együttes eloszlásmintázatában (2. ábra; $\chi^{2}$ próba, $\mathrm{p}<0,05$, mindkét nemben, minden korcsoportpár esetében): az életkor elörehaladtával a zsírBMI nagyobb értékei felé való eltolódás tendenciája mindkét nem esetében megfigyelhetö. 


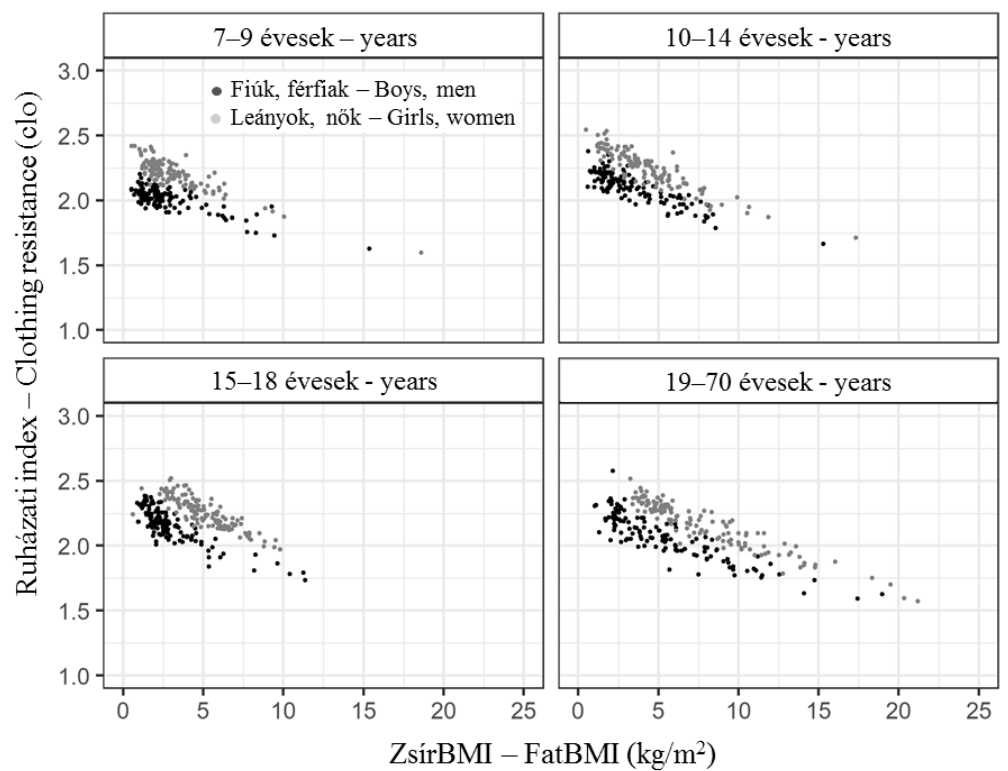

2. ábra: A zsírBMI és a becsült ruházati index kapcsolatának életkori és nemi mintázata téli időjárási viszonyok között ( $-10^{\circ} \mathrm{C}$-os kültéri hőmérséklet, $3 \mathrm{~m} / \mathrm{s}$ szélsebesség, 85\%-os levegö páratartalom, felhös ég).

Fig. 2: The relationship of fatBMI and the estimated clothing resistance index by age and sex in winter weather conditions $\left(-10^{\circ} \mathrm{C}\right.$ outdoor temperature, cloudy, $3 \mathrm{~m} / \mathrm{s}$ wind speed, $85 \%$ air humidity).

A két nem között is jelentős különbség figyelhető meg a zsírBMI és a ruházati index kapcsolatában, azonos mértékü zsírosság esetén a leányok és nők testszerkezeti mutatói alapján becsült ruházati index minden korcsoportban meghaladja a fiúk és férfiak azonos korcsoportjaiban becsült index-értékét, átlagosan $0,1-0,25$ clo értéknyi a két nem között ez a különbség (2. ábra; $\chi^{2}$-próba - minden korcsoportban: $p<0,05$ ). Ez az jelenti, hogy azonos korú, azonos zsírszázalékú nők és férfiak esetében a nők számára átlagosan 0,2 clo-nyival vastagabb ruházat biztosítja téli időjárás esetén a termikus komfortérzetet a 2-10 kg/m²-es zsírBMI tartományban (2. ábra). Ennél nagyobb mértékü zsírosság esetén a két nem ruházati index-értékében egyre kisebb különbség figyelhető meg téli időjárási viszonyok között.

A nyári időjárási viszonyokra becsült ruházati index és a zsírBMI kapcsolatát (3. ábra) elemezve megállapítható, hogy a zsírBMI növekedésével a ruházati index értéke csökken, azaz egyre nagyobb mértékü zsírosság esetén egyre vékonyabb hütőhatású ruházat is elegendő lenne a termikus komfortérzet kiváltásához - itt is nagyjából 0,5 clo hütőértékü a ruházatbeli különbség ötszörös zsírBMI különbség esetén (egyelöre hütőhatású ruházat nem került még ruhaipari forgalomba). A két mutató közötti kapcsolat a nyári időjárási viszonyok esetében is nagyon szoros, ebben az esetben szoros, pozitív kapcsolat igazolható közöttük minkét nem, minden korcsoportjában (Spearman korreláció, p<0,001 - fiúk és férfiak: 7-9 évesek: rho=0,597, 10-14 évesek: rho=0,755, 15-18 évesek: rho $=0,772$, felnőttek: rho $=0,872$; leányok és nők: $7-9$ évesek: rho $=0,724,10-14$ évesek: rho $=0,801,15-18$ évesek: rho $=0,864$, felnőttek: rho $=0,888$ ). 
Hasonlóan a téli időjárási viszonyokra becsült ruházati indexnél tapasztaltakhoz, a nyári időjárásra becsült ruházati index és zsírBMI kapcsolatának mintázata különbséget mutat a korcsoportok között (3. ábra; $\chi^{2}$-próba, p<0,05, mindkét nemben, minden korcsoportpár esetében). Szintén jelentős nemi különbség jelent meg a nyári időjárási viszonyokra becsült ruházati index és zsírBMI kapcsolatában (3. ábra; $\chi^{2}$-próba, p<0,05 minden korcsoportban). A $2-5 \mathrm{~kg} / \mathrm{m}^{2}$ zsírBMI tartomány esetében a téli időjárási viszonyokra becsültekhez hasonlóan a ruházati indexben ez nagyjából 0,2 clo-nyi nemi különbséget jelent azonos mértékű relatív zsírosság esetén, azonban ez a nemi különbség a nyári időjárási viszonyok között már az $5 \mathrm{~kg} / \mathrm{m}^{2}$-nél nagyobb zsírBMI esetében egyre kisebb a zsírosság mértékének növekedésével (3. ábra).

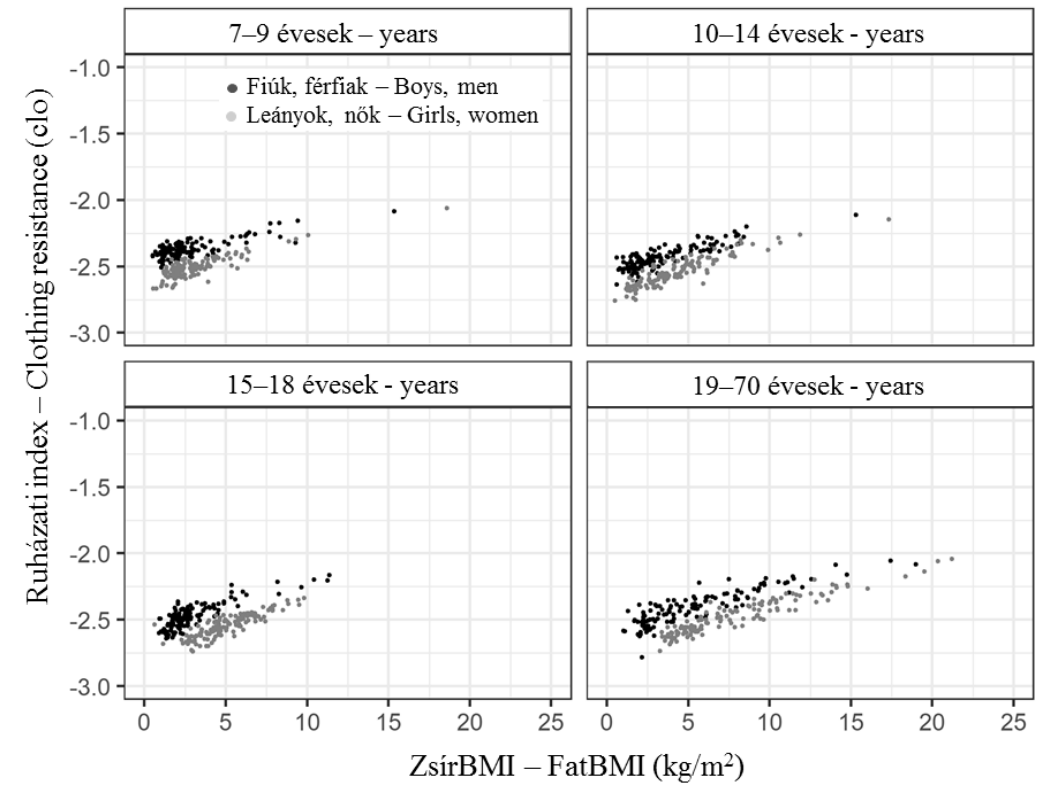

3. ábra: A zsírBMI és a becsült ruházati index kapcsolatának életkori és nemi mintázata nyári időjárási viszonyok között $\left(33^{\circ} \mathrm{C}\right.$-os kültéri hőmérséklet, 4,7 m/s szélsebesség, 40\%-os levegő páratartalom, napsütéses égbolt).

Fig. 3: The relationship of fatBMI and the estimated clothing resistance index by age and sex in summer weather conditions $\left(33^{\circ} \mathrm{C}\right.$ outdoor temperature, sunny, $4.7 \mathrm{~m} / \mathrm{s}$ wind speed, $40 \%$ air humidity).

Az izomBMI és a téli időjárási viszonyokra becsült ruházati index kapcsolata abban a tekintetben hasonlít a zsírBMI és ruházati index kapcsolatára, hogy az izomBMI növekedésével a ruházati index értéke tendenciáját tekintve csökken mindkét nem és minden korcsoport esetében (4. ábra), a két mutató között negatív korreláció igazolható, az életkor előrehaladtával a két mutató közötti korreláció erőssége fokozódik mindkét nem esetében (Spearman korreláció, p<0,001 - fiúk és férfiak: 7-9 évesek: rho=-0,280, 10-14 évesek: rho=-0,154, 15-18 évesek: rho=-0,725, felnőttek: rho=-0,743; leányok és nők: 7-9 évesek: rho=-0,502, 10-14 évesek: rho=-0,566, 15-18 évesek: rho=-0,597, felnőttek: rho=-0,679). 
Az izomBMI és a téli időjárási viszonyok alapján becsült ruházati index eloszlásmintázata a két nem között jelentősen különbözik mind a négy vizsgált korcsoportban (4. ábra, $\chi^{2}$-próba - minden korcsoportban: $\left.\mathrm{p}<0,05\right)$. A legfiatalabbak esetében azonos izomBMI esetén a leányoknál vastagabb ruházatot $(0,2-0,3$ clo-nyival nagyobb ruházati ellenállást) becsült a modell a termikus komfortérzet kialakításához, mint fiú kortársaiknál (4. ábra). A 10-14 évesek esetében a nemi különbség az izomBMI és a ruházati index eloszlásmintázatában a 7-9 évesek korcsoportjában tapasztalthoz hasonló tendenciát mutat, azzal a különbséggel, hogy a két nem eloszlásmintázata kezd átfedni ebben a korcsoportban. A 14 évestől idősebbek esetében az izomBMI és ruházati index együttes eloszlásmintázata alapján a két nem már újra jelentősen elkülönül egymástól - a leányok, nők izomBMI-je jelentősen kisebb, mint a fiú, férfi kortársaiknak (4. ábra).

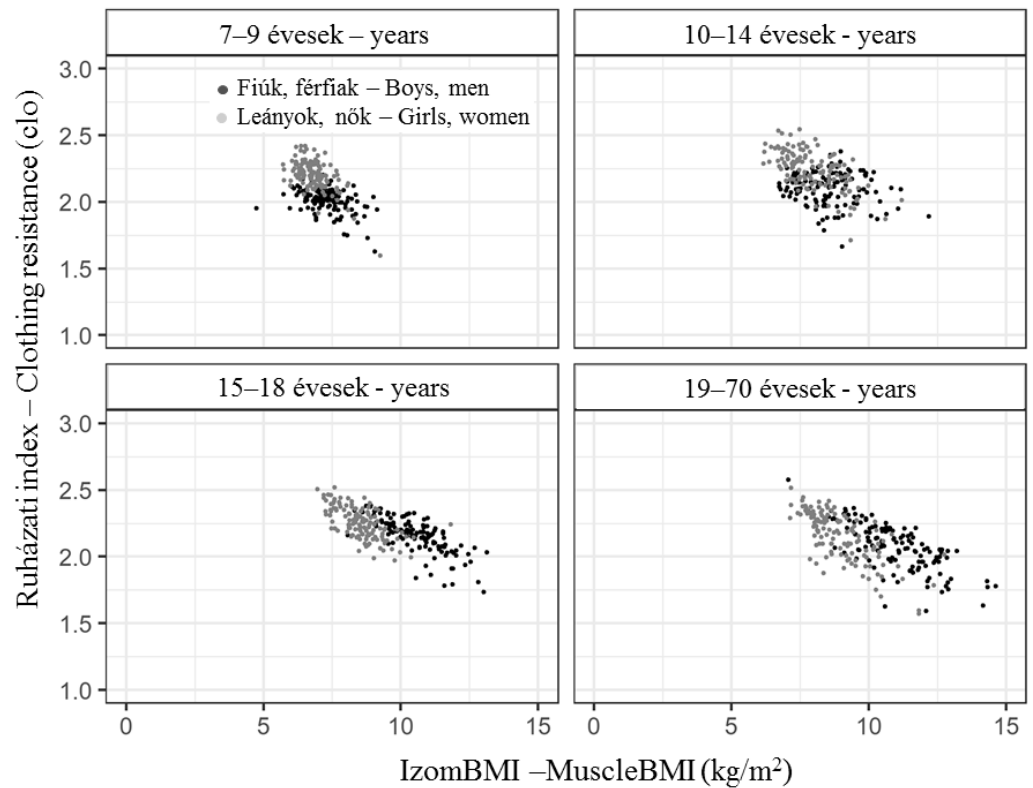

4. ábra: Az izomBMI és a becsült ruházati index kapcsolatának életkori és nemi mintázata tél időjárási viszonyok között $\left(-10^{\circ} \mathrm{C}\right.$-os kültéri hömérséklet, $3 \mathrm{~m} / \mathrm{s}$ szélsebesség, $85 \%$-os levegő páratartalom, felhös ég).

Fig. 4: The relationship of muscleBMI and the estimated clothing resistance index by age and sex in winter weather conditions $\left(-10^{\circ} \mathrm{C}\right.$ outdoor temperature, cloudy, $3 \mathrm{~m} / \mathrm{s}$ wind speed, $85 \%$ air humidity).

A nyári időjárási viszonyok alapján becsült ruházati index és az izomBMI kapcsolata nagyon hasonló a téli viszonyokra becsült index-értékek esetében leírtakhoz, azzal a különbséggel, hogy a minél nagyobb izomBMI a nyári viszonyok között egyre kisebb hütőértékű ruházati index értékkel jár együtt mindkét nem minden korcsoportjában (5. ábra). A nyári időjárási viszonyok esetében a két mutató között a korreláció a téli viszonyokra becsült korrelációhoz képest kevésbé szoros, és pozitív mindkét nem esetében (Spearman korreláció, p<0,001 - fiúk és férfiak: 7-9 évesek: rho=0,290, 10-14 évesek: rho $=0,167,15-18$ évesek: rho $=0,720$, felnőttek: rho $=0,712$; leányok és nők: $7-9$ évesek: rho=0,513, 10-14 évesek: rho=0,542, 15-18 évesek: rho=0,574, felnőttek: rho=0,688), amely korreláció erőssége az életkor előrehaladtával mindkét nem esetében fokozódik. 
Az életkori és nemi különbségek a téli viszonyokra becsült index-értékekhez hasonló tendenciájúak a nyári időjárási viszonyok szerint becsültek esetében: a termikus komfortérzet eléréséhez szükséges ruházati korrekció abszolút értékében a téli viszonyokra becsültekhez hasonló mintázatú mindkét nem esetében A különbség abban látható, hogy míg télen vastagabb fütő, addig nyáron nagyobb mértékben hűtő típusú ruházatot becsül a modell az azonos izomBMI-vel rendelkező leányoknak, mint a fiú kortársaiknak a 7-14 évesek korcsoportjaiban. Ez a típusú nemi különbség az életkor elörehaladtával már nehezen értelmezhető, hiszen a nők és férfiak két csoportja egyre inkább elkülönül relatív izomtartalmában, a férfiak egyedi izomBMI értékei egyre nagyobb tartományok felé tolódnak női kortársaik egyedi izomBMI értékeinek eloszlási mintázatához képest (5. ábra; $\chi^{2}$-próba, minden korcsoportban: $\mathrm{p}<0,05$ ).

A korcsoportok izomBMI - ruházati index eloszlásmintázatait összehasonlítva megállapítható, hogy az izomBMI értékek egyre nagyobb tartományok felé tolódnak el mindkét nem esetében az életkor előrehaladtával ( $\chi^{2}$-próba, mindkét nemben, minden korcsoportpár esetében, $\mathrm{p}<0,05)$.

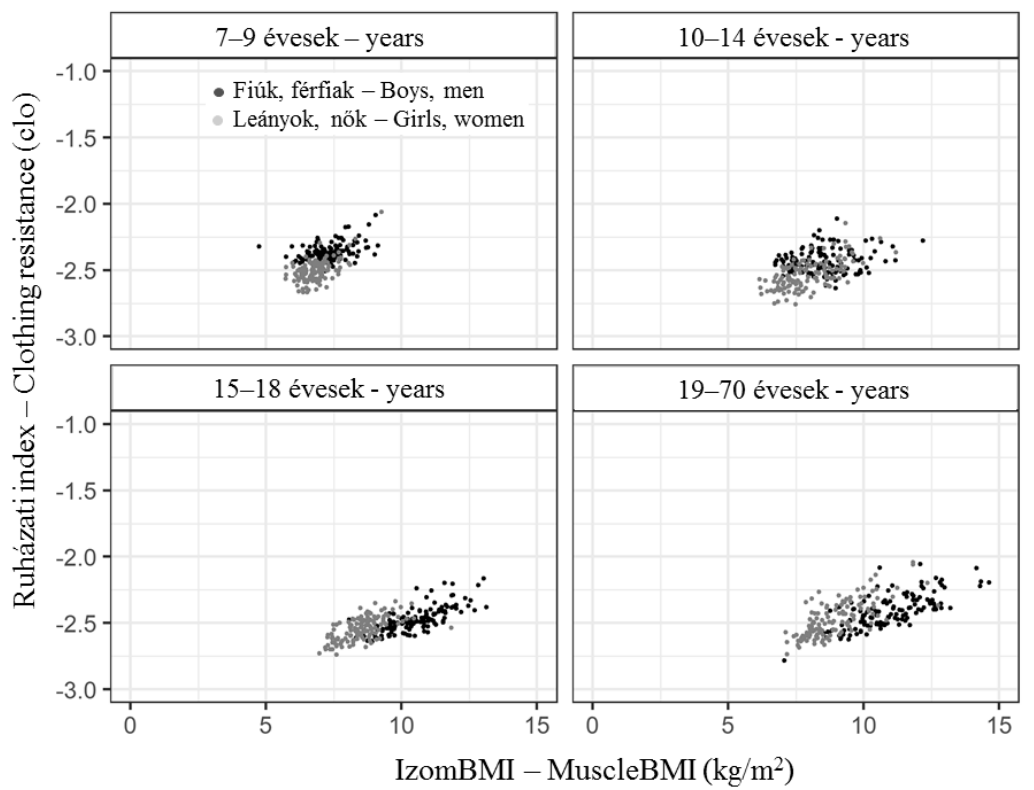

5. ábra: Az izomBMI és a becsült ruházati index kapcsolatának életkori és nemi mintázata nyári időjárási viszonyok között $\left(33^{\circ} \mathrm{C}\right.$-os kültéri hőmérséklet, $4,7 \mathrm{~m} / \mathrm{s}$ szélsebesség, 40\%-os levegő páratartalom, napsütéses égbolt).

Fig. 5: The relationship of muscleBMI and the estimated clothing resistance index by age and sex in summer weather conditions $\left(33^{\circ} \mathrm{C}\right.$ outdoor temperature, sunny, $4.7 \mathrm{~m} / \mathrm{s}$ wind speed, $40 \%$ air humidity).

Egyértelmüen igazolódott, hogy a zsír- és izomBMI is jelentős kapcsolatot mutat a termikus komfortérzet eléréséhez szükséges kültéri ruházati ellenállás mértékével. Azonban az is megállapítható, hogy a ruházati index mindezek alapján érzékenyebb az izomBMI egységnyi különbségeire, mint a zsírBMI esetében azt tapasztalhattuk mind a téli, mind pedig a nyári időjárási viszonyok között is. 
A relatív zsír- és izomtömeg együttes figyelembevételére elvégeztük elemzéseinket a testtömeg-index esetében is. A három vizsgált testszerkezeti mutató közül a BMI mutatta a legszorosabb kapcsolatot a ruházati ellenállás becsült értékével mindkét évszakban (6-7. ábra; Spearman korreláció, p<0,001 - téli időjárás, fiúk és férfiak: 7-9 évesek: rho=-0,611, 10-14 évesek: rho=-0,647, 15-18 évesek: rho=-0,918, felnőttek: rho=-0,966; leányok és nők: 7-9 évesek: rho=-0,810, 10-14 évesek: rho=-0,878, 15-18 évesek: rho= -0,958, felnőttek: rho=-0,951; nyári időjárás, fiúk és férfiak: 7-9 évesek: rho=-0,610, 10 14 évesek: rho=-0,642, 15-18 évesek: rho=-0,922, felnőttek: rho=-0,965; leányok és nők: 7-9 évesek: rho=-0,810, 10-14 évesek: rho=-0,880, 15-18 évesek: rho=-0,950, felnőttek: rho=-0,955). A nagyobb BMI-vel rendelkező emberek télen kisebb melegítö, illetve nyáron kisebb hütő hatású ruházati szigetelést igényelnek a modellünk becslése alapján.

A gyermekek két korcsoportjánál a különböző időjárási viszonyokra vizsgálva, a zsírBMI és izomBMI esetében leírt nemi különbség, miszerint azonos mértékü relatív zsír-, illetve relatív izomtömeg esetén a becsült ruházati ellenállás abszolút mértéke nagyobb a leányok csoportjában, mint a fiúknál, a BMI esetében is megjelent. Azonban ez a nemi különbség a 15 évesek korcsoportjától már nem igazolható a testtömeg-index esetében sem a nyári, sem a téli időjárási viszonyok között (6-7. ábra; $\chi^{2}$-próba - téli időjárás, 7-9 évesek: $\mathrm{p}=0,007,10-14$ évesek: $\mathrm{p}=0,028,15-18$ évesek: $\mathrm{p}=0,058$, felnőttek: $\mathrm{p}=0,156$; nyári időjárás, 7-9 évesek: $\mathrm{p}=0,004,10-14$ évesek: $\mathrm{p}=0,044,15-18$ évesek: $\mathrm{p}=0,116$, felnöttek: $\mathrm{p}=0,182)$.

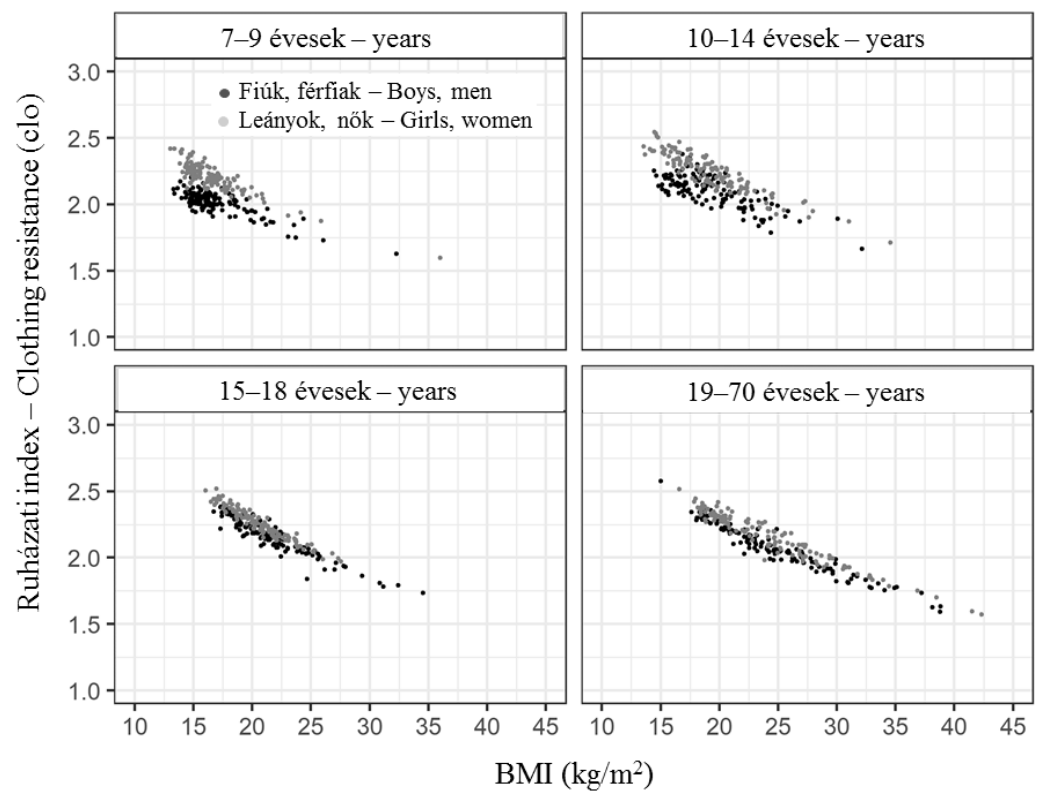

6. ábra: A BMI és a becsült ruházati index kapcsolatának életkori és nemi mintázata téli időjárási viszonyok között $\left(-10^{\circ} \mathrm{C}\right.$-os kültéri hőmérséklet, $3 \mathrm{~m} / \mathrm{s}$ szélsebesség, $85 \%$-os levegő páratartalom, felhős ég).

Fig. 6: The relationship of BMI and the estimated clothing resistance index by age and sex in winter weather conditions $\left(-10^{\circ} \mathrm{C}\right.$ outdoor temperature, cloudy, $3 \mathrm{~m} / \mathrm{s}$ wind speed, $85 \%$ air humidity). 


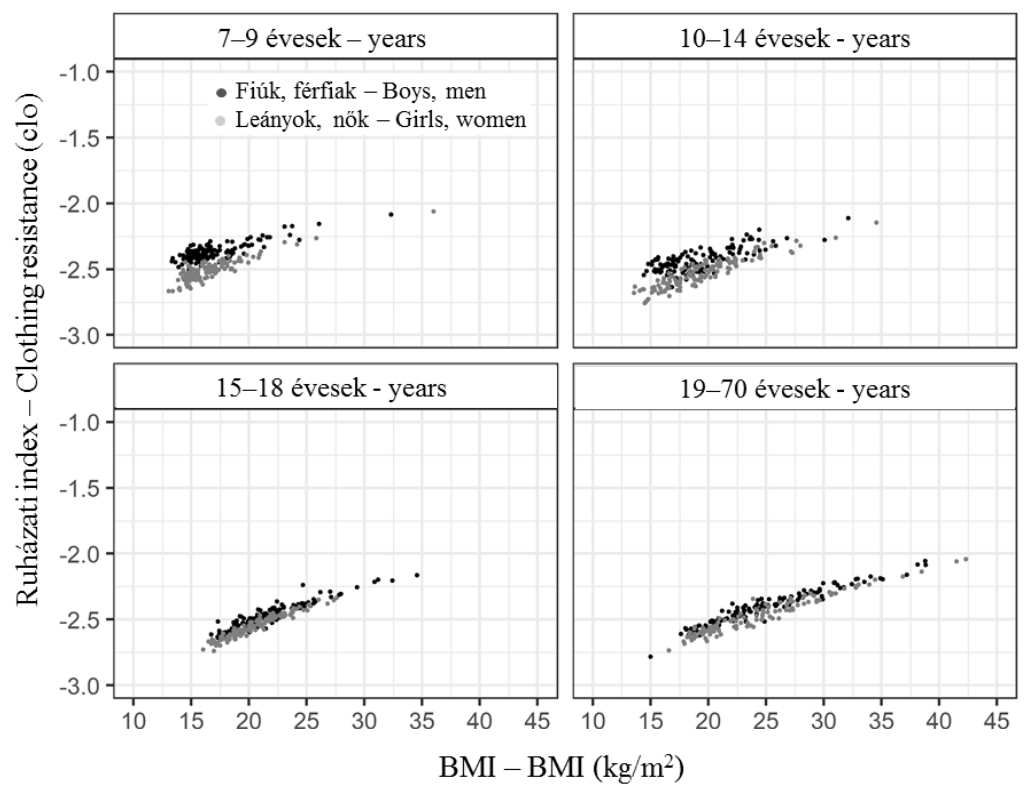

7. ábra: A BMI és a becsült ruházati index kapcsolatának életkori és nemi mintázata nyári időjárási viszonyok között $\left(33^{\circ} \mathrm{C}\right.$-os kültéri hömérséklet, $4,7 \mathrm{~m} / \mathrm{s}$ szélsebesség, $40 \%$-os levegő páratartalom, napsütéses égbolt).

Fig. 7: The relationship of BMI and the estimated clothing resistance index by age and gender in summer weather conditions $\left(33^{\circ} \mathrm{C}\right.$ indoor temperature, sunny, $4.7 \mathrm{~m} / \mathrm{s}$ wind speed, $40 \%$ air humidity).

\section{Következtetések}

A meteorológia tudományának 20. századi nagyon intenzív fejlődése lehetővé tette, hogy egy adott földrajzi régió várható időjárása nagy pontossággal előrejelezhető legyen néhány napos vagy akár 1-2 hetes intervallumra vonatkozóan is, amely előrejelzések már az okoseszközök korszakában mindenki számára elérhetők. Felmerült kutatócsoportunkban annak igénye, hogy ha az időjárás tényezői a humán tényezők mellett a fentiekben ismertetett mértékben hatással vannak hőterhelésünkre és így a höérzetünkre is, hogy egy adott földrajzi régióban, kültérre tervezett tartózkodás, ill. séta alkalmára ajánlott, komfortos viseletet biztosító ruházat becslésére képes modellt alkossunk, úgy, hogy modellünk a humán tényezők figyelembevételével a becslést egyénre szabottan tudja megadni. Az Eötvös Loránd Tudományegyetem Embertani Tanszéke és Meteorológiai Tanszéke együttmüködésében lehetőségünk adódott az egyedi időjárási és humán állapothatározói adatok alapján történő, a hőterhelés és az időjárási viszonyoknak megfelelö, optimális mértékủ ruházat höszigetelö mértékének elörejelzésére.

Elemzésünk eredményei alapján mind a relatív zsírtömeg, mind pedig a relatív vázizomtömeg kapcsolatot mutatott a nagy hötöbbletet, illetve nagy hőhiányt okozó időjárási helyzetekben a ruházati index-szel (a termikus komfortérzetet kialakító ruházat höszigetelésével) mindkét nem esetében végig a vizsgált korintervallumban. Minél nagyobb a relatív zsír-, illetve relatív izomtömeg, a termikus komfortérzet eléréséhez 
ajánlott ruházat ellenállási mutatójának abszolút értéke annál kisebb, azaz a vizsgált két testösszetevő minél nagyobb relatív tömegü egy emberi szervezetben, annál kisebb fütőértékü (vékonyabb) ruházatot jelez előre téli, és annál kisebb hütőértékü ruházatot jelez előre nyári időjárási viszonyokra. A két vizsgált testösszetevő hőszigetelő hatása igazolódott ezzel a modellkísérlettel. A zsírszövet szigetelő, míg az izomszövet hőtermelő hatása régóta közismert (Tuomaala és mtsai 2013), azonban az izomszövet hőszigetelő hatása mindezidáig kevésbé vizsgált tényező ebből a szemszögböl. Ráadásul ezen testszerkezeti jellemzők hőterhelésre, hőérzetre gyakorolt hatásait eddig hidegre, extrém hidegre modellezett időjárási viszonyok között elemezték, a két szövettípus nyári, meleg, extrém meleg időjárási viszonyok között megnyilvánuló szigetelő hatását nem vizsgálták még.

A női és férfi test szerkezetének különbségei a becsült ruházati index nemi különbségeiben is megnyilvánultak a vizsgált időjárási viszonyok között: tendenciáját tekintve elmondható, hogy azonos időjárási viszonyok között férfi kortársaikkal azonos zsír-, illetve izomBMI értékű nők számára a modell nagyobb abszolút értékủ ruházati indexet - azaz a termikus komfortérzet eléréséhez télen nagyobb fütőértékü, nyáron nagyobb hütő értékü ruházatot - becsült.

Természetesen az izom- és zsírtömeg mennyisége egymástól nem független összetevői az emberi testnek, különösen nagymértékü elhízás esetén igazolták eddig az epidemiológiai vizsgálatok (pl. Barbat-Artigas és mtsai 2014), hogy a relatív izom- és zsírtömeg szoros korrelációt mutat. Éppen ezért együttes hatásuk figyelembevételére a ruházati index és a testtömeg-index kapcsolatát is elemeztük. A vizsgált testszerkezeti mutatók közül a BMI állt a legszorosabb kapcsolatban a becsült ruházati ellenállás értékével. A BMI és a ruházati index együttes eloszlásmintázatának nemi különbsége 7-14 gyermekek körében kimutatható volt mind a nyári, mind a téli időjárási viszonyok között, azonban a 14 évesnél idősebbek esetében ez a nemi különbség megszünt.

Ez az elemzés abból a szempontból is kiemelt jelentőségü volt számunkra, hogy a ruházat hőszigetelésének mértékét egyedi szinten, adott időjárási viszonyokra előre jelezni hivatott, okoseszközre tervezett alkalmazás bemeneti, humán állapothatározói között nagy valószínüséggel kevés felhasználó tudja majd zsír-, illetve izomBMI értékét megadni, ezzel szemben a testmagasságból és testtömegböl levezetett BMI mutató minden bizonnyal mindenki számára becsülhető lesz. A BMI, a zsírBMI és az izomBMI, ruházat index, illetve a testszerkezeti mutatóknak a ruházati indexszel mutatott kapcsolatának életkori és nemi különbségeit elemezve arra következtethetünk, hogy

- a várható hőterhelés mértékének, valamint a komfortérzet eléréséhez ajánlott ruházat vastagságának (hőszigetelő képességének) előrejelzésekor indokolt az életkorra és a nemre vonatkoztatva a becsléseinket elvégezni,

- a kültéri tartózkodáshoz ajánlott ruházat vastagságának előrejelzésekor figyelembe veendő a testtömeg-index, mint egyedi, humán, testszerkezet jellemzésére alkalmas mutató - az eddig már kiválasztott életkor és nem egyedi, humán paraméterek mellett,

- ha van rá lehetőség, ajánlott azonban a zsír- és izomtartalom egy mutatóját (például a most bevezetett zsír- és izomBMI) értékét is a ruházat előrejelzésében figyelembe venni.

$$
* * *
$$

Tanulmányunkkal köszöntjük dr. Marcsik Antóniát és dr. Gyenis Gyulát 80. születésnapjuk alkalmából! 
Köszönetnyilvánítás: Kristóf Erzsébetnek a bemutatott kutatásban végzett munkáját a Széchenyi 2020 program, Magyarország Kormánya és az Európai Regionális Fejlesztési Alap támogatta (GINOP-2.3.2-15-2016-00028)

\section{Irodalom}

Ács, F., Kristóf, E., Zsákai, A. (2019): New Clothing Resistance Scheme for Estimating Outdoor Environmental Thermal Load. Geographica Pannonica, 23(4): 245-255. DOI: 10.5937/gp2323717

Ács, F., Zsákai, A., Kristóf, E., Szabó, A.I., Breuer, H. (2020a): Carpathian Basin climate according to Köppen and a clothing resistance scheme. Theoretical and Applied Climatology, 141: 299-307. DOI: 10.1007/s00704-020-03199-z

Ács, F., Zsákai, A., Kristóf, E., Szabó, A.I., Breuer, H. (2020b): Human thermal climate of the Carpathian Basin. International Journal of Climatology, megjelenés alatt. DOI $10.1002 /$ joc. 6816

Barbat-Artigas, S., Pion, C.H., Leduc-Gaudet, J.P., Rolland, Y., Aubertin-Leheudre, M. (2014): Exploring the role of muscle mass, obesity, and age in relationship between muscle quality and physical function. Journal of the American Medical Directors Association, 15(4): 303-313.

Budyko, M., Cicenko, V. (1960): Climatic factors of human thermal sensation (in Russian). Izvestiya Rossiiskoi akademii nauk. Seriya geograficheskaya, 3: 3-11.

de Freitas, C.R., Grigorieva, EA. (2015): A comprehensive catalogue and classification of human thermal climate indices. International Journal of Biometeorology, 59: 109-120. DOI: $\underline{10.1007 / \mathrm{s} 00484-014-0819-3}$

Fehér, P., Annár, D., Zsákai, A., Bodzsár, É. (2019): Pszichoszomatikus tünetek gyakoriságát befolyásoló tényezök 18-90 éves nök körében. Anthropologiai Közlemények, 60: 65-77. DOI 10.20330/AnthropKozl.2019.60.65

Haldane, J.B.S. (1905): The influence of high air temperatures. Journal of Hygiene, 5: 494-513.

Kántor, N. (2012): Városi közterületek termikus komfortviszonyainak értékelése Szeged példáján különös tekintettel a látogatók szubjektív reakcióira. Doktori disszertáció. SZE, Szeged.

R Core Team (2020): R: A language and environment for statistical computing. R Foundation for Statistical Computing, Vienna, Austria. www.R-project.org

Tuomaala, P., Holopainen, R., Piira, K., Airaksinen, M. (2013): Impact of individual characteristics such as age, gender, BMI and fitness on human thermal sensation. In: Proceedings of thirteen Internatinal Building Performance Simulation Association conference. pp. 2305-2311.

Utczás, K., Zsákai, A., Muzsnai, Á., Fehér, V. P., Bodzsár, É. (2015): Radiológiai és ultrahangos módszerrel végzett csontéletkor-becslések összehasonlító elemzése 7-17 éveseknél. Anthropologiai Közlemények, 56: 129-138. DOI: 10.20330/AnthropKozl.2015.56.129

Weiner, J.S., Lourie, J.A. (1969): Human Biology, A Guide to Field Methods.

Zsákai, A., Bodzsár, É. (2016): A reprodukciós öregedés és a csontszerkezet változásának kapcsolata nőknél. Anthropologiai Közlemények, 57: 77-84. DOI: $\underline{10.20330 / \text { AnthropKozl.2016.57.77 }}$

$\begin{array}{ll}\text { Levelezési cím: } & \text { Zsákai Annamária } \\ \text { Mailing address: } & \text { Embertani Tanszék } \\ & \text { Eötvös Loránd Tudományegyetem } \\ & \text { Pázmány P.s. 1/c. } \\ & \text { H-1117 Budapest } \\ & \text { Hungary } \\ & \text { annamaria.zsakai@ @tk.elte.hu }\end{array}$

